\title{
The New Statesman: I
}

\author{
BEATRICE WEBB
}

From The Diary of Beatrice Webb, vol. III: 1905-1924, ed. Norman and Jeanne MacKenzie (London: Virago, 1984) p. 188. The following extract opens the entry for 5 July 1913; the New Statesman had first appeared on 12 April. The Webbs wanted to start a reformist political weekly to follow up the Crusade, the organ of their Poor Law campaign, published between February 1910 and February 1913. Clifford Sharp had edited the Crusade and was an obvious choice to edit the new paper. He remained editor until 1931. Shaw put up $£ 1,000$ of the $£ 5,000$ initial capital and was a director until he resigned in October 1916, disagreeing with the direction the paper had taken. However, trouble arose early on from his refusal to sign his contributions.

GBS has in fact injured the New Statesman by his connection with it; we have had the disadvantage of his eccentric and iconoclastic stuff without the advantage of his name. Lots of people will think any article brilliant that they know is by him, whilst dismissing his anonymous contribution as tiresome and of no account, or as purely mischievous. And in all the details of his arrangements he is grossly inconsiderate, refusing to let Sharp know whether or not he was going to write, and what he was going to write about, until, on the day the paper goes to press, there appears on Sharp's table two or three columns - sometimes twice that amount - on any subject that he (Shaw) happens to fancy. Sharp has now decided that if Shaw insists on these terms we are better without him. Meanwhile, persons who subscribed for their weekly portion of Shaw are angry and say they were got to subscribe on false pretences. The New Statesman is in fact the one weekly in which Shaw's name never appears, and it is Shaw's name that draws, not his mind. He may become more considerate: he means to be kindly, but he is spoilt spoilt by intense vanity and intellectual egotism. He will not co-operate on terms of equality. 